\title{
RELATIONSHIP BETWEEN LEARNING ENVIRONMENT AND PERFORMANCE OF STUDENTS AT UNIVERSITY LEVEL
}

Maryam Munir ${ }^{1}$, Muhammad Shabbir $\mathrm{Ali}^{2}$, Asif Iqbal $^{3}$, Muhammad Faisal Farid ${ }^{4}$, Muhammad Siddique ${ }^{5 *}$

${ }^{1}$ Visiting Lecturer, University of Education Faisalabad Campus, Pakistan; ${ }^{2}$ Associate Professor Education, University of Education Faisalabad Campus, Pakistan; ${ }^{3}$ Associate Professor Education, University of Education Faisalabad Campus, Pakistan; ${ }^{4}$ Assistant Professor Education, University of Education Faisalabad Campus, Pakistan; ${ }^{5 *} \mathrm{Ph} . D$., Scholar, University of Education Lahore Pakistan.

Email: "siddiqueamar@gmail.com

Article History: Received on $22^{\text {nd }}$ May 2021, Revised on $2^{\text {nd }}$ June 2021, Published on $10^{\text {th }}$ June 2021

\section{Abstract}

Purpose of the study: The objectives were to investigate and correlate the learning environment of students and the performance of students at the university level.

Methodology: The study was descriptive. The study population consisted of the students currently studying at GC Women University Faisalabad. The data were computed using descriptive as well as inferential statistics. The selfdeveloped instrument, Learning Environment and Performance Survey [LEPS], was used.

Main Findings:-When the learning environment improves the performance of the students also increases strongly. The result showed the weak positive relationship of the learning environment with the performance of urban areas students. On the other hand, there were strong positive relationships of the learning environment with the performance of rural students.

Applications of this study: The study may be applied to investigate and improve the students' learning environment.

Novelty/Originality of this study: The female students had a better learning environment and significantly improved their achievement scores. Rural students had an insignificant difference in their learning environment and performance.

Keywords: Learning Environment, Performance of Students, Students' Achievement, Demographic Differences.

\section{INTRODUCTION}

The teacher must generate a classroom environment that is most favorable to enhance learning. In this way, the instructors promote awareness among students. It enhances learning and reduces behavioral difficulties, and establishes a healthy environment. Stone (2005) explored that environment is all the things around your surroundings. It may be the sounds, feelings, smells, and everything. A classroom also has an environment where the learning process of students complete. It is a survival skill for teachers to create a safe and healthy environment and boost the student's learning environment. Ullah (2020) investigated that the modern scientific view discloses teaching as difficult work. The basic components of the classroom environment are educational, social, and physical. These are essential for promoting a smooth process of education in the school.

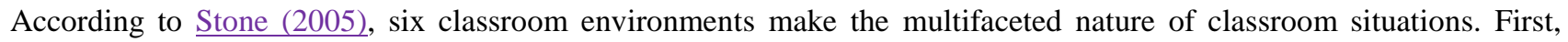
there is a broad range of events that are performed in the classroom setting. The students discuss, read, and write. They form friends, celebrate functions, argue, and play their games. The teacher plays the role of coach as well as a guide to settling disagreements among students. They direct students, discuss students' parents regarding the problems, and trace out the solution. The students discuss with the teacher a story, do personal writings, and play math games in small groups. It guarantees that being a teacher is seldom tedious, but impulsively can also be grueling. Classrooms are public places. In classroom premises, students' behaviors are apparent by their colleagues. Teachers discuss those students in different understanding. Finally, the students in classes are similar to families, which recall previous events positively or negatively.

\section{REVIEW OF RELATED LITERATURE}

The classroom learning environment is the collaboration between the instructor and his pupils and students (Adigwe, 2004). It is the students' learning through considerations of the relations between the activities of teachers and students and the nature of the variables that affect student outcomes during the learning process. It was measured with the help of a questionnaire named (WIHIC) by Aidridge and Fraser (2008) and Aldridge, Laugksch, \& Fraser (2006). The main dimensions are active interest, and participation in class discussions makes students active in performing extracurricular activities. It is a reflection of students' behavior in the class. It has dependent on the characteristics he or she brings to the classroom experience that will ultimately lead to such behaviors for better academic achievement scores, such as students discuss with one another for the solution of problems.

It is described as the collaboration of students instead of competition among students to perform learning tasks to achieve a common goal, such as teamwork, learn from other students. 
In this dimension, the teacher treats the students equally to enhance their achievement of students. The student is a key player in the classroom climate and needs equal praise and attention. Students' positive behavior to help, support, and support one another in classroom learning activities, become friendly to class members, and work well with other class. The inquiry method is used for investigation and problem-solving statements (Fraser, Aldridge, \& Adolphe, 2010). Other dimensions include affiliation, rule clarity, innovation, order, and organization. The dimensions that are based on meteorological and geographical features are called ecological dimensions. They are physical design and architectural features (Weintsein \& Mignano, 2007). According to Khan, Ullah, 2021; Ullah, (2020), the environment depends on participants' nature, while the leading aspects of an environment are measured as typical characteristics of members.

The beliefs, values, and meanings of the group that are collectively accepted are called culture. While working on the learning environment, Ullah (2020) investigated many aspects of the environment that are significant for learning activities. According to Stone (2005), the creation of a stimulating and successful classroom environment enhances lives. Teachers may make the present better than the past and the future better than the present within the classroom settings. When students are curious, think, explore experiments and ask questions, they learn best and discover new things.

\section{Historical Background of Learning Environments Research}

The researchers in the past (Dorman, 2002; Walker, 2004;) revealed that the learning environment is a newly initiated area in the educational field for 50 years. Therefore, the advancement was made to formulate, judge, and investigate the healthy learning environment of the classroom (Fraser, 2015; Ullah, 2020).

The research in that area started with the work of prominent researcher Moos. Moos (1974) developed three aspects. They were personal development, relationship, and system change to categorize the human environment. Moos (1974) developed an instrument to access a psychosocial classroom learning environment. The name of that instrument was "Classroom Environment Scale". Stone (2005)) developed a theory named "need-press theory" to demonstrate the needs of the individual while working in the environment. They are innate requirements, the personal and specific needs of individuals.

\section{Academic Performance or Achievement Score}

According to (Khan, Ullah, 2021; Ullah, 2020), the performance is the outward demo of thoughtful notions, services, thoughts, and information of an individual that grades signify the achievement score of students. According to $\underline{\text { Kobal and }}$ Musek (2001), academic performance represents the arithmetical scores of students' knowledge and the degree that he gains in schoolwork and the educational system. The achievement score of students may be achieved efficiently if all the factors affect students' educational presentation. Achievement outcome has been considered as a function of two characteristics, "skill" and "will "and these must be considered "and these must be considered individually because keeping the will alone may not assure success if the skill is lacking.

In all educational systems, performance is considered one of the significant factors of students' learning. Therefore, academic achievement is the main research area is now a day. In their effort to investigate the achievement score of students, many questions come to a researcher's mind. First, to locate aspects that affect the performance of students in the classroom. These factors are helping to improve students' academic achievement. According to (Aremu \& Oluwole, 2001; Ozcinar, 2006), students' learning outcomes and achievement scores can be judge through family status, institute, motivation, and society.

Self-esteem is an important element of good mental health. The concept of Self-esteem is broadly used in psychology. It is the sense of individuals of his or her self-confidence, self-respect, and worth. It is the degree to which a person admires or likes themselves (Blascovich \& Tomaka, 2014). Different studies had a positive relationship between selfesteem and the academic achievement score of students.

\section{Predictors of Academic Performance and Learning Environment}

\section{Socio-economic Status}

The socio-economical of families' such as financial resources, level of education, and occupational and professional status of parents is highly correlated with the academic achievement score of students (Sirin, 2005), which in turn forecasts the durability of students in educational institutions (Marjoribanks, 2005). Parental involvement enhances the children's progress (Gamoran, Turley, Turner, \& Fish, 2012). The support of parents creates an environment suitable for the growth of learners (Conger \& Donnellan, 2007). This idea supports the capital resources of the parents as a good interpreter of the child's academic achievement than social investment (Schlee, Mullis, \& Shriner, 2009).

\section{Parental Involvement}

Another best predictor of institutional adjustment in adolescence age is parental involvement (Carlson, 2006). It arbitrates the awareness of motivation and skills (Chouinard, 2007). These skills influence the students' involvement in their career decisions and their studies. The parents who were well aware of the child's academic growth promote positive contexts of learning that enable the growth of mastery goals ( $\underline{\text { Sideridis, 2005). }}$. 


\section{Motivational factors}

The factors related to students' motivation are the utmost forecasters of academic achievement (Covington, 2016). The studies regarding meta-analyses are identified associations between academic goals, skills related to academic learning, and academic results (Robbins et al., 2004). Furthermore, they revealed a strong association between students' motivations and academic-related skills (Crede \& Kuncel, 2008).

\section{Academic Goal}

The resources regarding resources to involvement and academic achievement took place based on the mobilization of individuals (Covington,2000; Eccles \& Wigfield, 2002), the study skills are also known as academic-related skills different study ways (Murray \& Wren,2003), attitudes toward study, and learning patterns.

Academic achievement is also related to cognitive styles, goals, and motives (Diseth \& Martinsen, 2003) and the appointment of students with their school (Caraway et al., 2003). The deliberate conduct and positive affect also predict the academic achievement of the students (Armitage, 2008).

\section{The Objectives of Students}

Contexts' characteristics influence the selection of objectives, and they are the dynamics between contextual factors and individual factors. The characteristics related to context are parents' characteristics, families, characteristics of schools, and student-teacher-interactions. All these characteristics are influenced by the objectives' choice (Eccles \& Wigfield, 2002). For example, the expansion of goals is related to parents' styles, the practices parental and they endorse the growth of capabilities which lead to academic achievement (Turner, Chandler, \& Heffer, 2009).

\section{The behavior of Teachers}

Teachers' behaviors contribute to development regarding the instrumental and motivational mechanisms (Moreira et al., 2010), and students select the supporting objectives (Stone, 2005). Student-teacher interactions are vital for advancing academic achievement (Rivkin, Hanushek, \& Kain, 2005) during the early years of schooling. Students make themselves the most positive and motivated learners with the directions of their teachers the knowledge and skills are improved by the students (Meece et al., 2006).

\section{Personality dimensions}

The personality dimensions are relevant to the motivation of individuals and their self-concepts. They are identified as psychobiological and contemporary personality models Stone (2005). These personality factors are systematically powerful forecasters of academic achievement.

\section{Statement of the Problem}

The environment is a prime factor that has a direct concern to educational attainment. It contains all those activities that assist in the achievement of students' classroom setting. Also, a learning environment is a bond between the students and teachers towards the attainment of goals. Quality of service is the concern of all educational processes. Unfortunately, in the context of Pakistan, many indicators affect the quality of educational institutions. Lack of a healthy learning environment and low service quality resulted in poor performance of students, which in turn makes the loss of resources. Hence the present study intends to explore the relationship between the learning environment and performance of students in public sector universities of Punjab.

\section{OBJECTIVES OF THE STUDY}

Following objectives were kept in mind while conducting this research:

1 To investigate the learning environment of students at the university level.

2 To examine the performance of students at the university level.

3 To investigate the correlation between the performance of learners and the learning environment at the university level.

4 To trace out the difference between male and female students' learning environment and their performance at the university level.

\section{Hypotheses}

The hypotheses drawn based on the objectives were as under:

$\mathbf{H}_{\mathbf{0 2 3}}$ : There is no significant difference between students' learning environment and academic achievement scores based on gender.

$\mathbf{H}_{\mathbf{0 2 5}}$ : There is no significant difference between students' learning environment and academic achievement score based on location. 


\section{The Significance of Current Study}

1. The study would be beneficial on the following grounds:

2. This would be a humble addition to the existing hoard of knowledge.

3. This study would be useful in improving the service quality and learning environment at the university level.

4. This study would be beneficial to compare the service quality of students at the university level.

5. This study would be beneficial to explore students' academic performance at the university level if the learning environment and service quality are improved.

\section{RESEARCH DESIGN}

It was a descriptive research study based on a survey to explore the relationship among learning environment, service quality, and Students' performance at the university level.

\section{The population of the study}

The study consisted of the students currently enrolled in GC University Faisalabad and GC Women University Faisalabad. The students were taken from these universities who were enrolled in BS Honors and Masters Classes.

\section{Sample of the Study}

As the study explored the relationship between the learning environment and students' performance at the university level, equal departments (three sciences and three arts departments) from these universities were selected. Due to the gender and location of the respondents, they were distributed in male, female, urban, and rural categories. A total of six hundred and fifty-eight students were selected randomly from those universities. From which 86 males and 572 were female. Four hundred and fifty-seven students from urban areas and 201 from rural areas were randomly selected. Two hundred and sixty-two science students and 398 art students were randomly selected.

\section{Instrument and its Validity}

The self-developed instrument, Learning Environment and Performance Survey [LEPS]. The instrument was pilot tested for its validity. In addition, this instrument was validated independently by a panel of experts in the field. The experts belonged to the field of education and research. They verified the face as well as the content validity of the instrument.

\section{Reliability of the Instrument}

The reliability of the instrument was 0.899 .

Table 1: Item Breakup of Learning Environment

\begin{tabular}{ccc}
\hline S. No & Factors of the Scale & Item Number \\
\hline 1 & Physical & $2,6,17,26,27,30$ \\
\hline 2 & Cooperation & $5,12,20,24,25$ \\
3 & Academic & $3,6,13,14,18,21,23,29$ \\
4 & Presentation & $1,7,9,11,19,28$ \\
5 & Motivation & $4,8,10,15,22$ \\
\hline
\end{tabular}

Table 1 showed that five factors have thirty items. They have subdivided into learning environment five items; Physical six items; Cooperation 5 items; Academic 8 items; Presentation 6 items and Motivation 5 items.

$\mathrm{H}_{\mathrm{o1}}$ : There is no significant relationship between the learning environment and the performance of male students.

Table 2: Correlation of Learning Environment with Performance of Male Students

\begin{tabular}{ccccc}
\hline Location & $\mathbf{N}$ & & Performance & $\boldsymbol{P}$-Value \\
\hline Male & 86 & Learning Environment & .107 & $.000^{* *}$ \\
\hline
\end{tabular}

$* * \mathrm{P}<0.01$

The correlation was run to see the relationship between the learning environment and the performance of male students. It revealed from table 2 that there is a significant relationship between the learning environment (.107) with the performance of male students. So, the null hypothesis about the correlation of the learning environment with the performance of male students was rejected. It was concluded that when the learning environment increases, the performance of students also increases. The results of "Pearson $\mathrm{r}(.107, \mathrm{P}<0.01)$ " showed the weak and positive relationship of the learning environment with the performance of male students.

$\mathbf{H}_{02}$ : There is no significant relationship between the learning environment with the performance of female students. 
Table 3: Correlation of Learning Environment with Performance of Female Students

\begin{tabular}{ccccc}
\hline Location & $\mathbf{N}$ & & Performance & $\boldsymbol{P}$-Value \\
\hline Female & 572 & Learning Environment & .053 & $.000^{* *}$ \\
\hline
\end{tabular}

$* * \mathrm{P}<0.01$

The correlation was run to see the relationship between the learning environment and the performance of female students. It revealed from table 3 that there is a significant relationship between the learning environment (.053) with the performance of female students. So, the null hypothesis about the correlation of the learning environment with the performance of female students was rejected. The results of "Pearson $\mathrm{r}(.053, \mathrm{P}<0.01)$ " showed the weak positive relationship of the learning environment with the performance of female students.

$\mathrm{H}_{03}$ : There is no significant relationship between the learning environment with the performance of science students.

Table 4: Correlation between Learning Environments with Performance of Science Students

\begin{tabular}{ccccc}
\hline Subject & N & & Performance & P-Value \\
\hline Science & 260 & Learning Environment & .134 & $.000^{* *}$ \\
\hline
\end{tabular}

$* * \mathrm{P}<0.01$

The correlation was run to see the relationship between the learning environment and the performance of science students. It revealed from table 4 that there is a significant relationship between the learning environment (.134) with the performance of science students. So, the null hypothesis about the correlation between the learning environment and science students' performance was rejected. It is concluded that when the learning environment increases, the performance of the students also increases. The result of "Pearson $r(.134, p<0.01 \& 0.05)$ " showed the strong positive relationships of the learning environment with the performance of science students.

$H_{04}$ : There is no significant relationship between the learning environment and the performance of art students.

Table 5: Correlation of Learning Environment with Performance of Arts Students

\begin{tabular}{ccccc}
\hline Subject & N & & Performance & $P$-Value \\
\hline Arts & 398 & Learning Environment & .052 & $.000^{* *}$ \\
\hline
\end{tabular}

$* * \mathrm{P}<0.01$

The correlation was run to see the relationship between the learning environment and the performance of art students. It revealed from table 5 that there is a significant relationship between the learning environment (.052) with the performance of art students. So, the null hypothesis about the correlation of the learning environment with the performance of art students was rejected. Therefore, it is concluded that when the learning environment increases, the students' performance also increases strongly.

$\mathrm{H}_{05}$ : There is no significant relationship between the learning environment and the performance of urban students.

Table 6: Correlation between Learning Environments with Performance of Urban Students

\begin{tabular}{ccccc}
\hline Location & $\mathbf{N}$ & & Performance & $\boldsymbol{P}$-Value \\
\hline Urban & 457 & Learning Environment & .073 & $.000^{* *}$ \\
\hline
\end{tabular}

$* * \mathrm{P}<0.01$

The correlation was run to see the relationship between the learning environment and the performance of urban students. It revealed from table 6 that there was a significant relationship between the learning environment (.073) with the performance of urban students. So, the null hypothesis about the correlation of the learning environment with the performance of urban students was rejected. It is concluded that when the learning environment increases, the performance of the students also increases. The result of "Pearson $\mathrm{r}(.073, \mathrm{P}<0.01)$ " showed the weak positive relationship of the learning environment with the performance of students.

$H_{06}$ : There is no significant relationship between the learning environment and the performance of rural students.

Table 7: Correlation between Learning Environment and Performance of Rural Students

\begin{tabular}{ccccc}
\hline Location & $\mathbf{N}$ & & Performance & $\boldsymbol{P}$-Value \\
\hline Rural & 201 & Learning Environment & .122 & $.000^{* *}$ \\
\hline
\end{tabular}

$* * \mathrm{P}<0.01$ 
The correlation was run to see the relationship between the learning environment and the performance of rural students. It revealed from table 7 that there was a significant relationship between the learning environment (.122) with the performance of rural students. So, the null hypothesis about the correlation between the learning environment and rural students' performance was rejected. It is concluded that when the learning environment increases, the performance of the students also increases. The result of "Pearson $\mathrm{r}(.122, \mathrm{p}<0.01 \& 0.05$ levels)" showed the strong positive relationships of the learning environment with the performance of rural students.

$\mathrm{H}_{0_{7}}$ : There is no significant difference between the learning environment and performance of male and female students.

Table 8: Difference between Learning Environment and Performance of Male and Female Students

\begin{tabular}{ccccccc}
\hline Gender & N & Mean & SD & Df & t-value & P-value \\
\cline { 1 - 5 } Males & 86 & 107.6395 & 17.02864 & \multirow{2}{*}{656} & \multirow{2}{*}{-2.432} & \multirow{2}{*}{$.017^{*}$} \\
\hline Females & 572 & 112.2850 & 12.58502 & & & \\
\hline
\end{tabular}

$* \mathrm{P}<0.05$

Table 8 revealed a significant difference between male $(M=107.6395, S D=17.02864)$ and female students $(\mathrm{M}=112.2850, \mathrm{SD}=12.58502), \mathrm{t}(656)=-2.432$. So, the null hypothesis about the difference between the learning environment and male and female students" was rejected. It was found that male and female students had a significant difference in their learning environment and performance. The mean achievement score found that female students had a better learning environment, and they gained a significant performance in their achievement scores at the university level.

$\mathrm{H}_{08}$ : There is no significant difference between the learning environment and performance of urban and rural students.

Table 9: Difference between Learning Environment and Performance of Urban and Rural Students

\begin{tabular}{lllllll}
\hline Location & N & Mean & SD & df & t-value & $P$-value \\
\hline Urban & 457 & 111.4245 & 13.18456 & \multirow{2}{*}{656} & -.735 & .463 \\
\cline { 1 - 5 } Rural & 201 & 112.2537 & 13.66273 & & & \\
\hline
\end{tabular}

Table 9 revealed an insignificant difference between urban $(\mathrm{M}=111.4245, \mathrm{SD}=13.18456)$ and rural students $(\mathrm{M}=112.2537, \mathrm{SD}=13.66273)$, $\mathrm{t}(656)=--.735$. So, the null hypothesis about the correlation between learning environment and performance of urban and rural students" was accepted. It was found that urban and rural students had an insignificant difference in their learning environment and performance. The mean achievement score found that urban and rural students showed equal performance under the learning environment at the university level.

\section{DISCUSSION AND CONCLUSION}

It was found that male and female students had a significant difference in their learning environment and performance. The study supported the study of (Cloninger et al. 1993; Khan, Ullah, 2021; Ullah, 2020) that individuals' motivations and self-concepts have been identified as personality dimensions and contemporary personality models such as the psychobiological model of personality. Personality measurements have systematically been shown to be one of the stronger predictors of academic performance. It was concluded that when the learning environment increases, the performance of students also increases. The current study results showed the weak positive relationship of the learning environment with the performance of female students. It was concluded that when the learning environment increases, the performance of the students also increases. When the learning environment increases, the performance of the students also increases strongly. The result showed the weak positive relationship of the learning environment with the performance of students. There were strong positive relationships of the learning environment with the performance of rural students. The mean achievement score found that female students had a better learning environment, and they gained a significant performance in their achievement scores at the university level. It was found that urban and rural students had an insignificant difference in their learning environment and performance. The mean achievement score explored that female student have a better learning environment, and they gained a significant performance in their achievement scores at the university level. It was found that male and female students had an insignificant difference in their service quality and performance. The mean achievement score found that male and female students have equal opinions on service quality and performance in their achievement scores.

The prior studies in the relevant field stressed on the socio-economical of families' such as financial resources, level of education, and occupational and professional status of parents is highly related to student's academic achievement (Sirin, 2005), which in turns the forecasts the permanence of students in educational institutions (Marjoribanks, 2005). Parental involvement enhances the children's progress. The factors related to students' motivation are the utmost forecasters of academic achievement. The studies regarding meta-analyses are identified associations between academic goals, skills related to academic learning, and academic results (Robbins et al., 2004). They revealed a strong association between students' motivations and academic-related skills (Crede \& Kuncel, 2008). 
The resources regarding resources to involvement and academic achievement took place based on the mobilization of individuals (Covington, 2000; Eccles \& Wigfield, 2002), the study skills are also known as academic-related skills, different study habits (Murray \& Wren,2003), and learning patterns.

\section{LIMITATIONS AND FUTURE RESEARCH}

The present study is limited to examine the association between learning environment and students' performance at the university level, however, future studies can be conducted to analyze the relationship between learning environment and vocational students at the diploma level as that also contribute a significant role in the state-building. In addition, the association between learning environment and performance of in comparison to other developed and under-developed economies can also be conducted.

\section{RECOMMENDATIONS}

This study is useful for top-level management at the university level in order to analyze the influence of the learning environment on students' performance.

\section{AUTHORS' CONTRIBUTIONS:}

Maryam Munir: Data Analysis and its interpretation, Abstract and Conclusion writing, review of the article after completion, and correspondence with the journal.

Muhammad Shabbir Ali: Data Collection, working on Literature, writing references and after completion of research review the article

Asif Iqbal: Data Collection, working on Literature and after completion of research, its review.

Muhammad Faisal Farid: Data Collection, working on Literature and after completion of research, its review.

Muhammad Siddique: Data Collection, working on Literature and after completion of research, its review.

\section{REFERENCES}

1. Adigwe, J. C. (2004). School climate and chemistry classroom environment of senior secondary schools. Benin Journal Educational Studies, 18(2), 83-89.

2. Aldridge, J. M., \& Fraser, B. J. (2008). Outcomes-focused learning environments: Determinants and effects. Rotterdam, the Netherlands: Sense Publishers. https://doi.org/10.1163/9789087904982

3. Aldridge, J. M., Laugksch, R. C., \& Fraser, B. J. (2006). School-level environment and outcomes-based education in South Africa. Learning Environments Research, 9, 123-147. https://doi.org/10.1007/s10984-0069009-5

4. Armitage, C. (2008). Cognitive and affective predictors of academic achievement in schoolchildren. British journal of psychology, 99, 57-74. https://doi.org/10.1348/000712607X181313

5. Aremu, A. O., \& Oluwole, D. A. (2001). Gender and birth other as predictors of Normal pupil's anxiety pattern in examination. Ibadan Journal of Educational Studies, 1(2), 58-66.

6. Astin, A. (1990). The environmental assessment technique: A way to measure college environments. Journal of Educational Psychology, 52. 72-97.

7. Caraway, C., Tucker, C. M., Reinke, W. M., \& Hall, C. (2003). Self-efficacy, goal orientation, and fear of failure as predictors of school engagement in high school students. Psychology in the Schools, 40, 417 - 427. https://doi.org/10.1002/pits.10092

8. Carlson, M. J. (2006). Family Structure, Father Involvement, and Adolescent Behavioral Outcomes. Journal of Marriage and Family, 68(1), 137-154. https://doi.org/10.1111/j.1741-3737.2006.00239.x

9. Carr, M., Borkowski, J., \& Maxwell, S. (1991). Motivational components of underachievers. Developmental Psychology, 27, 108-118. https://doi.org/10.1037/0012-1649.27.1.108

10. Chouinard, M. M. (2007). Children's questions: A mechanism for cognitive development. Monographs of the Society for Research in Child Development, 72(1), 113-26. https://doi.org/10.1111/j.1540-5834.2007.00421.x

11. Cloninger, C. R., Svrakic, D. M., \& Przybeck, T. R. (1993). A psychobiological model of temperament and character. Archives of General Psychiatry, 50, 975-990. https://doi.org/10.1001/archp syc. 1993.01820240059008

12. Conger, R. D., \& Donnellan, M. B. (2007). An interactionist perspective on the socioeconomic context of human development. Annual Review of Psychology, 58, 175-199. https://doi.org/10.1146/annurev. psych.58.110405.085551

13. Crede, M., \& Kuncel, N. (2008). Study Habits, Skills, and Attitudes: The Third Pillar Supporting Collegiate Academic Performance. https://doi.org/10.1111/j.1745-6924.2008.00089.x

14. Diseth, A., \& Martinsen, O. (2003). Approaches to learning, cognitive style, and motives as predictors of academic achievement. Educational Psychology, 23(2), 195-207. https://doi.org/10.1080/01443410303225

15. Dorman, J. P. (2002). Classroom Environment Research: Progress and Possibilities. Retrieved from http://www.iier.org.au/qjer/qjer18/dorman. HTML 
16. Eccles, J. S., \& Wigfield, A. (2002). Motivational beliefs, values, and goals. Annual Review of Psychology, 53, 109-132. https://doi.org/10.1146/annurev.psych.53.100901.135153

17. Fraser, B. J., Aldridge, J. M., \& Adolphe, G. (2010). A cross-national study of secondary science classroom environments in Australia and Indonesia. Research in Science Education, 40, 551-571. https://doi.org/10.100 7/s11165-009-9133-1

18. Gamoran, A., Turley, R. N. L., Turner, A., \& Fish, R. (2012). Differences between Hispanic and non-Hispanic families in social capital and child development: First-year findings from an experimental study. Research in Social Stratification and Mobility, 30(1), 97-112. https://doi.org/10.1016/j.rssm.2011.08.001

19. Khan, K. M., Ullah M. (2021). Mediating Role of Ethical Leadership Between Employees Empowerment and Competitive Edge: A Case of Commercial Banks in Pakistan. Humanities \& Social Sciences Reviews, 9(2), 219-221. https://doi.org/10.18510/hssr.2021.9223

20. Marjoribanks, K. (2005). Family environments and children's outcomes. Educational Psychology, 25, $647-657$. https://doi.org/10.1080/01443410500344704

21. McCombs, B. L., \& Marzano, R. J. (1990). Putting the self in self-regulated learning: The self as an agent in integrating will and skill. Educational psychology, 25, 51-69. https://doi.org/10.1207/s15326985ep2501 5

22. Meece, J. L., \& Anderman, E. M., \& Lynley, A. (2006). Classroom Goal Structure, Student Motivation, and Academic Achievement. Annual review of psychology, 57, 487-503. https://doi.org/10.1146/annurev. psych.56.091103.070258

23. Moreira, P. A. S., Pinheirob, A., Gomesc, P., Cotterc, M. J., \& Ferreirac, R. (2010). Development and Evaluation of Psychometric Properties of an Inventory of Teachers' Perceptions on Socio-Emotional Needs. Psychology: Reflection and Criticism, 26(1), 67-76. https://doi.org/10.1590/S0102-79722013000100008

24. Murray, C., \& Wren, C. T. (2003). Cognitive, Academic, and Attitudinal Predictors of the Grade Point Averages of College Students with Learning Disabilities. Journal of Learning Disabilities, 36(5), 407-15. https://doi.org/10.1177/00222194030360050201

25. Mynster, D. (1997). Classroom management. Retrieved on 3 March 2008, from www.AltaVista.com

26. Ozcinar, Z. (2006). The instructional communicative Qualification of parents with students. Cypriot Journal of Educational Sciences, 1, (2), 29-48.

27. Robbins, S. B., Lauver, K., Le, H., Davis, D., Langley, R., \& Carlstrom, A. (2004). Do psychosocial and study skill factors predict college outcomes? A meta-analysis. Psychological Bulletin, 130, 261-288. https://doi.org/10.1037/0033-2909.130.2.261

28. Rivkin, S. G., Hanushek, E. A., \& Kain, J. F. (2005). Teachers, schools, and academic achievement. Econometrica, 73(2), 417-458. https://doi.org/10.1111/j.1468-0262.2005.00584.x

29. Schlee, B. M., Mullis, A. K., \& Shriner, M. (2009). Parents' social and resource capital: Predictors of academic achievement during early childhood. Children and Youth Services Review, 31(2), 227-234. https://doi.org/10.10 16/j.childyouth.2008.07.014

30. Sideridis, G. D. (2005). Goal Orientation, Academic Achievement, and Depression: Evidence in Favor of a Revised Goal Theory Framework. Journal of Educational Psychology, 97(3), 366-375. https://doi.org/10.103 7/0022-0663.97.3.366

31. Sirin, S. R. (2005). Socioeconomic Status and Academic Achievement: A Meta-Analytic Review of Research. Review of Educational Research, 75(3), 417- 453. https://doi.org/10.3102/00346543075003417

32. Stone, R. (2005). Practices best classroom management: For reaching all learners. California: Corwin press, a sage Publication company.

33. Turner, E. A., Chandler, M., \& Heffer, R. W. (2009). The influence of parenting styles, achievement motivation, and self-efficacy on academic performance in college students. Journal of College Student Development, 50(3), 337-346. https://doi.org/10.1353/csd.0.0073

34. Ullah, M. (2020). Women Empowerment and Social Development in Afghanistan through Micro Finance. International Journal of Academic Research in business and Social Sciences, 10(12), $377-389$ https://doi.org/10.6007/IJARBSS/v10-i12/8324

35. Walker, S. L. (2004). Learning Environment Research (Learning Environments Monograph No. 2). San Marcos, TX: Texas State University-San Marcos, Geography Department.

36. Weinstein, C. S., \& Mignano, A. J. (2007). Elementary classroom management: Lessons From Research and Practice. New York: McGraw Hill Co. 